\title{
The impact of technology-enhanced organisational learning on business performance: An empirical study ${ }^{*}$
}

\author{
Tanja Arh, Borka Jerman Blažič, Vlado Dimovski*
}

This paper focuses on a presentation of the conceptualization of a structural model that was developed to examine the impact of technology-enhanced learning and organizational learning on the business performance of some Slovenian companies with more than 50 employees. In accordance with the stakeholder theory and balanced scorecard (BSC), both the financial and nonfinancial aspects of the performance are considered. The results of the study indicate the strong impact of technology-enhanced learning on organizational learning and non-financial business performance.

Im Mittelpunkt des vorliegenden Beitrages steht die Präsentation der Konzeptualisierung eines strukturellen Modells, das entwickelt wurde, um die Auswirkung von technologisch unterstütztem und organisiertem Lernen auf den Unternehmenserfolg slowenischer Firmen mit mehr als 50 Beschäftigten zu testen. Gemäß der Stakeholder-Theorie und der Balanced-Scorecard-Methode (BSC), werden sowohl finanzielle als auch nicht-finanzielle Erfolgsaspekte berücksichtigt. Die Ergebnisse der Studie zeigen eine starke Auswirkung des technologisch unterstützten Lernens auf das organisatorische Lernen und auf den nicht-finanziellen Unternehmenserfolg.

Keywords: organizational learning, business performance, research model, LISREL

\footnotetext{
Manuscript received: 24.11.10, accepted: 04.03.12 (3 revisions)

** Tanja Arh, Jožef Stefan Institute, Ljubljana, Slovenia. Main research areas: organizational learning, knowledge management, technology-enhanced learning, organizing and decision making. Corresponding address: tanja@e5.ijs.si

Borka Jerman Blažič, Jožef Stefan Institute, Ljubljana, Slovenia. Main research areas: organization and management, internet technologies, security in networking, business research methods.

Vlado Dimovski, Faculty of Economics, Ljubljana, Slovenia. Main research areas: strategic management, business research methods, organizational learning, organizational learning culture
} 


\section{Introduction}

Nowadays, information-communication technologies (ICTs) enable us to access a wide range of different sources of knowledge. Mastering this knowledge is becoming crucial for successful operations, and represents an important source of a company's competitive advantage. When companies intend to acquire knowledge by educating their employees, suitable methods can be based on ICT, Web 2.0 technologies and technology-enhanced learning (Tel). Technologyenhanced learning, as a way of knowledge acquisition, has been widely adopted as a promising solution by many companies in order to offer learning-ondemand opportunities to individual employees and to reduce training times and cost. Through technology-enhanced learning, workers have access to various online databases, tools and e-services that help them find solutions to work-related problems (Zhang/Nunamaker 2003). Organisational learning (Ol) has emerged as a key factor for success within the process of replacing physical capital with human resources. A study of organisational learning is relevant as it seeks to respond to the challenges that arise in a constantly changing business environment and can help companies confront their long-term survival difficulties. Organisational learning thus represents a source of heterogeneity and a potential source of sustainable, competitive advantages (Easterby-Smith et al. 2000; Lei et al. 1999).

Indeed, extensive empirical research has provided support for the notion that companies that manage their organisational learning processes better are also better off in terms of financial and non-financial results (e.g., Bontis/Crossan/ Hulland 2002; Jimenez-Jimenez/Cegarra-Navarro 2007; Skerlavaj/Dimovski 2004; Škerlavaj/Indihar Štemberger/Škrinjar/Dimovski 2007).

This paper presents the results of a study involving 356 Slovenian companies with more than 50 employees that aimed to examine the impact of technologyenhanced learning and organisational learning on both the financial (Fp) and non-financial performance (Nfp).

The paper has seven main sections. The first section provides definitions of technology-enhanced learning and Web 2.0 technologies. The second section presents the theoretical framework and background of our research study. The third, fourth and fifth sections provide a definition of the research model and hypotheses, the development of the research instrument, and the research procedure. We conclude with a discussion and the managerial implications of the results, and offer some guidelines for future research.

\section{The theoretical framework}

For the purposes of our research study, we use the concept of technologyenhanced learning, defined as a process that supports any learning activity through technology (Gold et al. 2001). It includes an informationcommunication infrastructure, learning technologies and learning content that 
support different utilization characteristics of knowledge and learning activities (Leonard-Barton 1995), such as: technologies for the collaboration of knowledge, knowledge discovery, localization and use, knowledge generation and storage, etc. (Real et al. 2006).

When talking about technology-enhanced learning the impact of Web 2.0 technologies should not be overlooked. These Web 2.0 technologies are changing the way people share their knowledge, perspectives, opinions, thoughts and experiences across the web. Web 2.0 tools, such as instant-messaging systems, blogs, RSS, social bookmarking, VideoWiki, Doodle, podcasts and picture-sharing sites are becoming more and more popular (Arh et al, 2011). Web 2.0 is involved in various knowledge-management processes, including knowledge creation (Alavi/Leidner 2001; Pawlowsky et al. 2001) and thus contributes to the sustainability of competitive advantage through its interaction with other resources.

The analysis of organizational learning has become an increasingly important study area over the past couple of years. Various authors (Argyris/Schön 1996; Senge 1990; Jones 2000; Nonaka/Takeuchi 1996; Wall 1998; Shrivastava 1983; Dimovski 1994) have analysed this construct from different viewpoints. With this in mind, the focus has either been on a psychological approach (Cyert/March 1963), a sociological approach (Nelson/Winter 1982; Levitt/March 1998), or an organizational theory approach (Cangelosi/Dill 1965; Senge 1990; Huber 1991). More recently, learning has been considered as a source of heterogeneity among organizations, as well as a potential basis for a competitive advantage from a strategic prospective (Grant 1996; Lei et al. 1996; Lei et al. 1999; Dimovski et al. 2007; Dimovski 1994; Dimovski/ Škerlavaj 2005; Arh 2010).

The development of our research model is based on DiBelle and Nevis' model (DiBella/Nevis 1998) of an integrated approach and on the Dimovski approach (Dimovski/Colnar 1999), and as a result combines three aspects of organisational learning: knowledge acquisition (observation of the environment inside and outside the company), the transfer of knowledge (dissemination of good practices among the company staff) and the use of knowledge (concrete data collection, research and findings have been directly used in a concrete environment - at a work place or within the work-process improvement procedures).

The modern business environment demands a multi-goal orientation characterised by the increased importance and strength of customers, employees and society in general. It has become obvious that all stakeholders need to be taken into account in a modern company-performance assessment (Bergant 1998; Kovač/Jesenko 2010). The profit theory (Cyert/March 1963) is no longer a valid measure of the company's performance. This is because, besides the financial performance, the non-financial performance must also be assessed in 
order to evaluate the overall business performance. Several approaches to the selection of non-financial indicators exist (Freeman 1984; 1994); however, the balanced scorecard, i.e., BSC, (Kaplan/Norton 1992) is the best-known approach.

Findings based on a broad overview and systematisation of the literature has confirmed the positive impact of ICT and technology-enhanced learning on both organisational learning and business performance. The impact of organisational learning was clearly indicated in financial results (Lei et al. 1999; Slater/Narver 1995), in results related to shareholders (Goh/Richards 1997; Ulrich et al. 1993) and in business results (Leonard-Barton 1992). Mintzberg (1990) and Perez et al. (2004) indicated that a company's performance is an important piece of feedback information relating to the effectiveness and efficiency of the learning processes.

\section{Research model and hypotheses}

A flow chart offers the best possibility of a graphical representation of the interrelations between various elements of a model. In Figure 1 the measurement variables belonging to exogenous latent variables are marked with an $\mathrm{x}$, while their measurement deviations are marked with an $\delta$. The endogenous latent variable indicators are marked with a y, and the measurement deviations with an $\varepsilon$. The structural equation deviations are $\zeta$, the exogenous latent variables are $\xi$, the endogenous constructs are $\eta$, and the one-way influences of the exogenous latent variables on the exogenous are $\gamma$. To describe the relations between the latent variables and their measurement variables we use $\lambda$.

Figure 1 shows a conceptualised research model that presents all the basic constructs and the hypothesized correlations between them. We aim to prove the following: (H1) that the latent variable of technology-enhanced learning (Tel) has a positive impact on organisational learning $(\mathrm{Ol}),(\mathrm{H} 2)$ financial $(\mathrm{Fp})$ and (H3) non-financial performance (Nfp); and (H4) that organisational learning (Ol) leads to improved financial results (Fp) as well as to (H5) improved nonfinancial results (Nfp). 
Figure 1: The research model

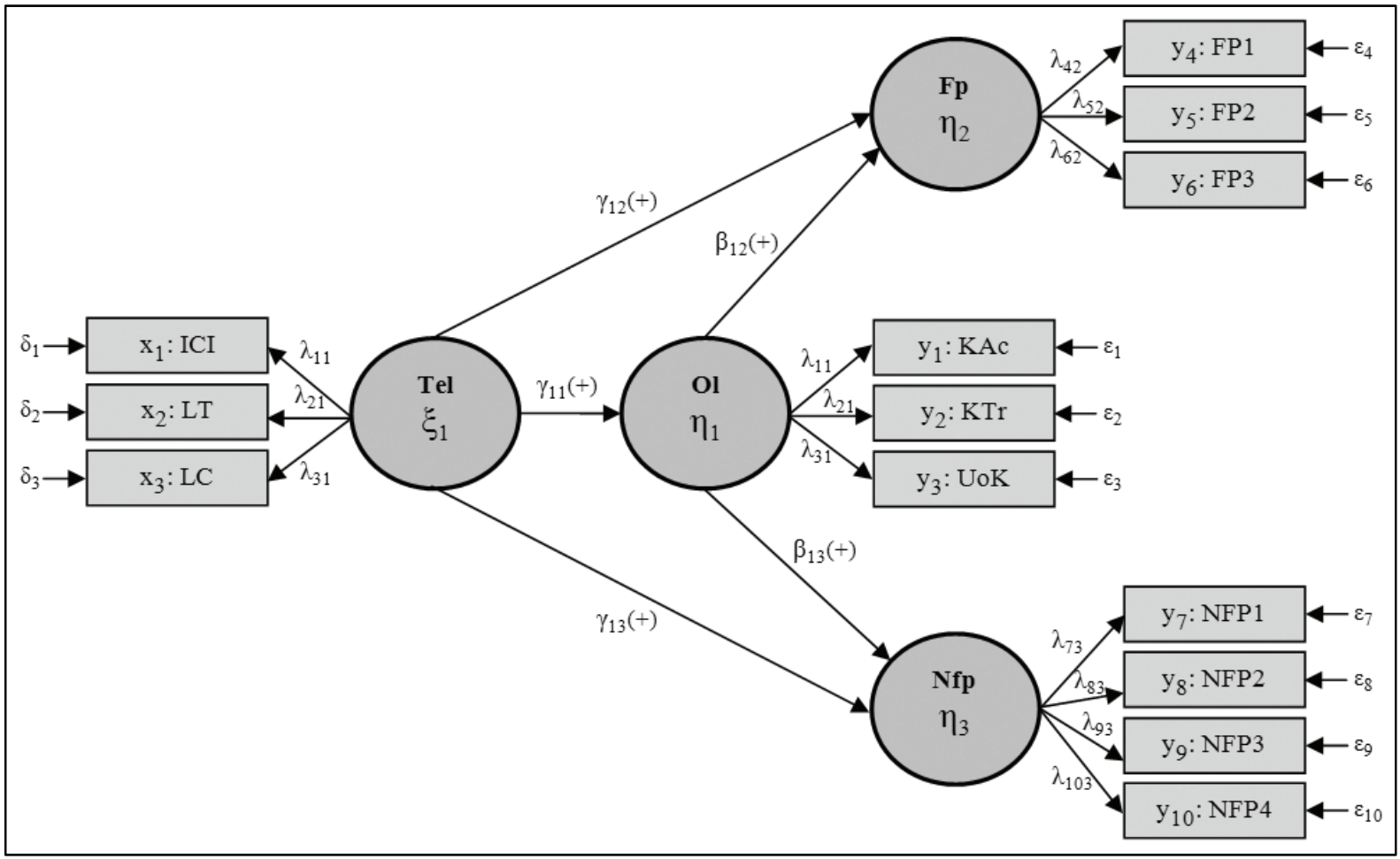

\section{Research instrument}

For the purposes of the model's operationalization a questionnaire with 4 constructs, 13 measurement variables and 57 items was developed. The questionnaire uses 5-point Likert scales, applied to a sample of Slovenian companies with more than 50 employees in 2007. The measurement instrument has 22 items for the Tel construct and 29 items for the $\mathrm{Ol}$ construct. The financial performance ( $\mathrm{Fp})$ was measured with three one-item measurement variables: return on assets (ROA), return on equity (ROE), and added value per employee (AVEMP) over the last three years relative to the industry average, using the bipolar scale. The same approach was used for the non-financial performance $(\mathrm{Nfp})$ to capture the perspectives of other stakeholders in a company (fluctuation of employees, customer loyalty, customer complaints, and the stability of relationships with suppliers).

\section{Research methodology and results}

The research model was tested using the methodology of structural equation modelling (SEM). This involves a combination of confirmatory factor analysis (CFA) and econometric modelling, which aims to analyse the hypothesised relationships among the latent constructs, measured with observed indicators (measurement variables). The relationships between the constructs were estimated using LISREL 8.80 with the correlation matrix and the asymptotic covariance matrix as the inputs. 
First, an item analysis was performed to describe the sample characteristics, to investigate the item means, and to assess the item-to-total correlations. Second, an exploratory factor analysis (EFA) was performed to explore the underlying structure of a collection of observed variables. After the EFA, the reliability of the underlying factors was discussed in terms of Cronbach's alphas. Third, a confirmatory analysis (CFA) was performed to ensure that the constructs were valid and reliable; this refers to the measurement part of the model. Consequently, CFAs were performed with LISREL 8.80 to check whether the items meet the criteria for convergent and discriminant validity, as well as construct reliability. The properties of the four research constructs in the proposed model and the five hypotheses were tested by the LISREL 8.80 and PRELIS 2.30 packages for the structural equation analysis and procedures (Diamantopoulos/Siguaw 2000). The maximum likelihood (ML) was used as the estimation method for the model evaluation and procedures.

\section{Data gathering and sample}

Based on the model's conceptualisation, a questionnaire was developed and sent in June 2007 to the CEOs or board members of all the Slovenian companies with more than 50 employees (1215 companies). The response rate was $29.7 \%$, which can be considered as successful in the Slovenian context (using our primary data-collection technique and no call backs). We aimed at an audience of top and middle managers (directors of functional departments), bearing in mind the idea of having a strategic and to some degree even an interdisciplinary perspective on the company in question, although there is some discrepancy between the desired and actual structure of the respondents. Based on the criterion of the average number of employees, in $200673.88 \%$ of the selected companies had between 50 and 249 employees, followed by $14.61 \%$ with 250 to 499 employees, while $11.51 \%$ of the companies had 500 to 999 employees. According to the company revenues in 2006, 33.15\% of the Slovenian companies had annual revenues of between $€ 2$ million and $€ 7.3$ million. A somewhat smaller proportion $(32.87 \%)$ of the companies had, during that period, a net income from $€ 7.3$ million to $€ 29.2$ million, $19.94 \%$ had an annual turnover of more than $€ 29.2$ million, and only $14.04 \%$ did not reach the threshold of $€ 2$ million in annual revenues. Table 1 demonstrates the industry structure of the companies. In almost half of the cases the main industry was manufacturing, followed by $13.8 \%$ of companies in the construction business, and $11.5 \%$ in wholesale \& retail, repair of motor vehicles, personal and household goods. One company out of fifteen industries only had one representative, while there was no company stating fishery and only two companies stating education as their main industry. This is logical since we excluded the non-profit and small businesses from our analysis. 
Table 1: Structure of respondents - by industry

\begin{tabular}{|ll|l|l|}
\hline Industry (EU NACE Rev.1) & Frequency & Percent (\%) \\
\hline A & Agriculture, hunting and forestry & 7 & 2 \\
\hline B $\quad$ Fishing & 0 & 0 \\
\hline C & Mining and quarrying & 7 & 2 \\
\hline D & Manufacturing & 158 & 44.4 \\
\hline E & Electricity, gas and water supply & 15 & 4.2 \\
\hline F & Construction & 49 & 13.8 \\
\hline G & $\begin{array}{l}\text { Wholesale \& retail, repair of motor vehicles, } \\
\text { personal \& household goods }\end{array}$ & 41 & 11.5 \\
\hline H & Hotels and restaurants & 12 & 3.4 \\
\hline I & Transport, storage and communication & 14 & 3.9 \\
\hline $\mathrm{J}$ & Financial intermediation & 7 & 2 \\
\hline $\mathrm{K}$ & Real estate, renting and business activities & 16 & 4.5 \\
\hline $\mathrm{M}$ & Education & 2 & 0.6 \\
\hline $\mathrm{N}$ & Health and social work & 1 & 0.3 \\
\hline $\mathrm{O}$ & Other community, social and personal services & 27 & 7.6 \\
\hline
\end{tabular}

\section{Parameter value estimates}

The results of the SEM by LISREL were used to test the proposed hypotheses. The relationships between the constructs were examined based on t-values associated with the path coefficients between the constructs. If an estimated tvalue is greater than a certain critical value $(\mathrm{p}<.05$, $\mathrm{t}$-value $=1.96)$ (Mueller 1996), the null hypothesis that the associated estimated parameter is equal to 0 was rejected. Subsequently, the hypothesized relationship was supported.

The maximum likelihood (ML) method was used to estimate the parameter values. In this phase, the hypotheses posed in the conceptualisation phase are tested. Even though several methods can be used for this purpose, ML is the one most often used and has the advantage of being statistically efficient and at the same time specification-error sensitive because it demands only complete data and does not allow for the missing values (Škerlevaj/Dimovski 2004; Jöreskog/Sörbrom 1993). Figure 2 shows a path diagram of our model with completely standardised parameter estimates. 
Figure 2: Research model (completely standardised parameter values, *significant at $p>0.05)$.

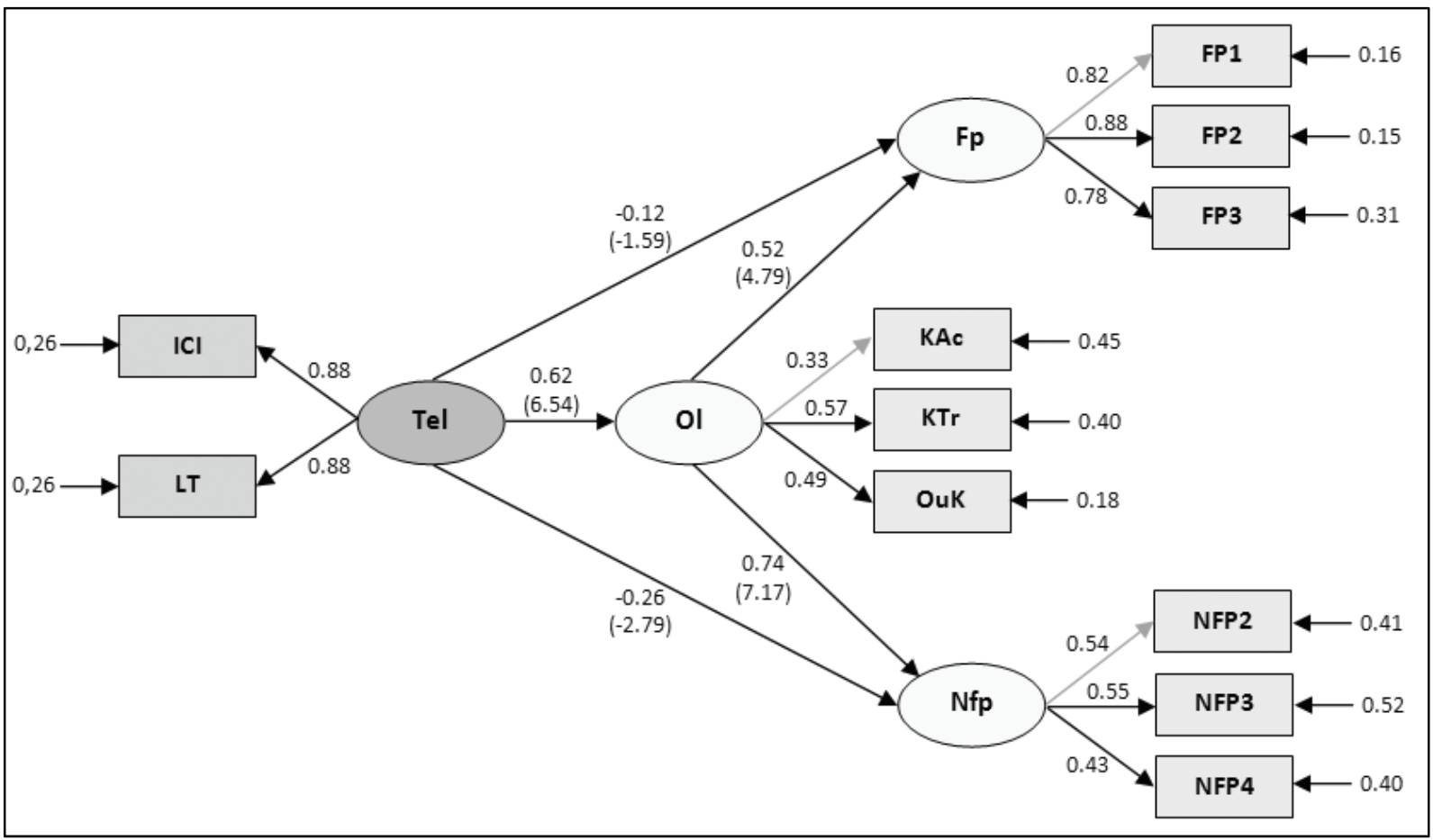

The technology-enhanced learning (Tpu) demonstrated a statistically significant, positive and strong impact on organization learning (Ol). Namely, the value of the completely standardised parameter almost equals the margin of 0.70 . Technology-enhanced learning did not exhibit any statistically significant impact on the financial performance ( $\mathrm{Fp}$ ), meaning that hypothesis 2 must be rejected. The organization learning construct demonstrated a statistically significant positive and strong impact on Fp and an even stronger one on the non-financial performance (Nfp). This means that hypotheses 4 and 5 can be considered to have empirical support from the data at hand.

\section{Global fit assessment}

Bollen (1989) explained that model fit relates to the degree to which a hypothesised model is consistent with the available data - the degree to which the implicit matrix of covariances (based on the hypothesised model) and the sample covariance matrix (based on the data) fit. The aim of the global fit assessment is to determine the degree to which the model as a whole is consistent with the gathered data (Škerlevaj/Dimovski 2004). Through the years, numerous global fit indices have been developed. However, to the dismay of researchers, none of them is superior to the others. Diamantopoulos and Siguaw (2000) recommend using several measures and at the same time provide reference values for every one of them (Table 2). 
Table 2: Fit indices.

\begin{tabular}{|c|c|c|c|}
\hline Fit indices & Reference value & Model value & Global fit \\
\hline $\begin{array}{l}\text { Chi-square }(\chi 2) \text { of estimate } \\
\text { model }\end{array}$ & $\left(\chi^{2} / \mathrm{df}<2\right)$ & $\begin{array}{c}89.29(\mathrm{df}=38)= \\
2.34\end{array}$ & No \\
\hline Goodness-of-fit index (GFI) & $\geq .90$ & .96 & Yes \\
\hline $\begin{array}{l}\text { Root mean square residual } \\
\text { (RMR) }\end{array}$ & $<.05$ & .023 & Yes \\
\hline $\begin{array}{l}\text { Root mean square error of } \\
\text { approximation (RMSEA) }\end{array}$ & $\leq .05$ & .062 & Yes \\
\hline CAIC & $\begin{array}{c}\text { CAIC saturated } \\
\text { model } \\
\text { CAIC independent } \\
\text { model }\end{array}$ & 281.79 & Yes \\
\hline $\begin{array}{l}\text { Adjusted goodness-of-fit index } \\
\text { (AGFI) }\end{array}$ & $\geq .90$ & .92 & Yes \\
\hline Non-normed fit index (NNFI) & $\geq .95$ & .97 & Yes \\
\hline Normed fit index (NFI) & $\geq .90$ & .96 & Yes \\
\hline $\begin{array}{l}\text { Parsimony goodness-of-fit } \\
\text { index(PGFI) }\end{array}$ & $\geq .50$ & .55 & Yes \\
\hline Comparative fit index (CFI) & $\geq .90$ & .98 & Yes \\
\hline Critical $(\mathrm{CN})$ & $\mathrm{N}=248.77$ & 356 & Yes \\
\hline
\end{tabular}

The most traditional value is the $\chi^{2}$ statistics. Using this fit indicator we test the hypothesis that the implicit covariance matrix equals the sample covariance matrix. Our goal is not to reject this hypothesis. In our case, this hypothesis must be rejected (at a 5\% level of significance). However, quantifying the degree of misfit is often more useful than testing the hypothesis of the exact fit, which $\chi^{2}$ statistics are designed for. All the other indices lead to the conclusion that the model is an appropriate representation of reality. The root means square error of approximation (RMSEA) is the most widespread measure of global fit and in our case points to the acceptable fitness of the model. The Consistent Akaike Information Criterion (CAIC) of the model needs to be compared against the CAIC for the saturated and independent model, where smaller values represent a better fit. The standardised root mean square residual (standardised RMR) is a fit index calculated from the standardised residuals (the differences between elements of the sample and implicit covariance matrixes). The goodness-of-fit (GFI) index and the adjusted goodness-of-fit (AGFI) index are absolute fit indices, which directly assess how well the covariances based on parameter estimates reproduce the sample covariances (Gebring/Anderson 1993). All of 
the indices described above lead to the conclusion that the model can be regarded as an appropriate approximation of reality (at the global level).

\section{Discussion and managerial implications}

Empirical research results have confirmed a strong, positive correlation between technology-enhanced learning and organisational learning. The strong connection proves that investments in ICT and learning technologies lead to higher-level organisational learning. The companies using different ICT tools in their daily business have recognized organisational learning as the most efficient process for the acquisition, transfer and use of knowledge. Technologyenhanced learning flattens the company's structure and promotes a greater dissemination of information to employees. The company becomes better informed, more flexible and organic. The greater availability of information helps the employees to further disseminate the information and enhance the learning processes. In this way, knowledge becomes the company's essential asset, while the business operations gain a healthy transparency.

The correlations between technology-enhanced learning and financial business results did not support hypothesis 2 . Namely, the interpretation of the obtained results did not confirm that the companies with a larger scope of investments and application of ICT achieve better financial business results. Obviously, modern learning technologies could not be a guarantee of high investments. For efficient accumulation, transfer and use of knowledge, a number of comprehensive and systematic, interconnected and interdependent changes have to be implemented at all corporate levels to create a business-support environment. The company has to communicate its new vision to the employees and the wider public, making everyone aware of the company's new knowledgeoriented business approach and knowledge-based path to achieve its goals.

Testing hypothesis 3 led to some interesting findings referring to the correlation between technology-enhanced learning and non-financial business results. The impact of technology-enhanced learning and ICT on non-financial business results, such as the share of loyal customers, the number of complaints and the quality of the relations with suppliers, is statistically significant, medium strength, but negative. For Slovenia - according to many indicators, economically the most developed country within the EU-10 group 2004 - it brought some interesting observations. Slovenian companies with more than 50 employees are relatively well equipped with an information-communication infrastructure (36\% of them have an ERP system, 97\% have access to an intranet, $10 \%$ use LAN, $35 \%$ use Web 2.0 technologies), but the level of concrete exploitation varies considerably. Where companies fail to meet the whole functional range of a certain business on a daily basis, they can be regarded as a missed opportunity, which is also evident from our study. The promises of technology vendors, with their well-known standardized software 
solutions (e.g., ERP systems) helping to manage the supplier chain, solve the problems that the company has with its customers, productivity, education and training of employees and employee satisfaction, are in our research study unfulfilled.

The companies that introduced the concept of organisational learning are more successful, in both financial and non-financial terms. The companies with a better-developed concept of organisational learning produced a higher return on assets (ROA), return on equity (ROE), and added value per employee. They have better employee relations, as well as more stable relations with suppliers and clients. Still, the top management's support remains crucial in order to achieve the sustainability of the learning organisation's initiative design (Arh et al. 2008). In this way, the category of knowledge has radically strengthened its predominant role of an essential generator of competitive advantage. Our empirical study and findings speak in favour of this statement.

The main findings presented so far decisively influence the prevailing management paradigm through the whole prism of the four fundamental functions of management, i.e., planning, organising, leading and controlling. The management of the company should strive to establish a positive organisational culture supporting learning cooperation and empowerment. Within this perspective the decisive role has been given to the remuneration system, which should motivate the employees to take a proactive approach to achieving the common strategic goals of the company, mutual trust, exchange of information, etc. This new quality of relations is demonstrated through the usage of different ICT tools (like forums, blogs, wiki, ERP systems, virtual community of the employees, etc.) in the light of strengthening the business success of the company.

\section{Conclusions}

The aim of this paper was to present one of the possible models for assessing the impact of ICT and technology-enhanced learning on the organizational learning and business performance of Slovenian companies with more than 50 employees. With this in mind, five hypotheses were tested. A sample of previously collected data was used throughout the survey questionnaire, circulated to the CEOs and presidents of the management boards. The empirical part of the study was analysed by the means of the structural equation modelling (SEM) methodology.

The results of the study indicate the strong impact of technology-enhanced learning on organizational learning and non-financial business performance. The companies that invest more effort in achieving higher-level organisational learning gain in both financial and non-financial terms. These results are consistent with previous empirical research (Dimovski 1994; Sloan et al., 2002; 
Figueiredo 2003) and confirm that knowledge is definitely one of the most important criteria for the competitive advantage of companies.

We should always be aware of the limitations of our research and the directions for future research stemming from these origins. Some of the study's strengths could also turn out to be its weaknesses. From the methodological point of view, the sample and context are always an issue. We used a sample of Slovenian companies with more than 50 employees in 2007. Taking Slovenia as a target population contributes to the research's generalizability, but could also be its weakness. The authors acknowledge that smaller companies might show other patterns of behaviour; this is for sure one of the challenges for future research. Or still far reaching - further expansion of the research to introduce a crosscultural dimension to the context and to cross-validate the model in different settings (e.g., South-Eastern Europe, EU countries, etc.) would significantly contribute to a better understanding of the link between ICT, organizational learning and business performance. The positive effect established in onecountry research needs to be tested in cross-cultural settings by using rigorous statistical methods such as multigroup structural equation modelling. In addition, the next step is to examine the organisational learning process in several case studies, on an individual, group and organisational level by using for instance the social network analysis approach to organisational learning (Škerlevaj/Dimovski 2006). Future research should also extend the understanding of the organizational learning by involving some moderating and mediating variables, for instance, besides information acquisition also the quality of information obtained might be in question.

\section{References}

Alavi, M./Leidner, D.E. (2001): Review: Knowledge management and knowledge management systems: Conceptual foundations and research issues, in: MIS Quarterly, $25,1,107-136$.

Argyris, C./Schön, D.A. (1996): Organizational Learning II: Theory, Method and Practice. Reading, MA: Addison-Wesley.

Arh, T. (2010): Impact of Technology Enhanced Organisational Learning on Business Performance. Doctoral dissertation. Faculty of Economics, Ljubljana.

Arh, T./Dimovski, V./Jerman-Blažič, B. (2008): Model of impact of technology-enhanced organizational learning on business performance, in: Cunningham, P./Cunningham, M. (eds.). Collaboration and the knowledge economy: issues, applications, case studies, (Information and communication technologies and the knowledge economy, vol. 5). Amsterdam [etc.]: IOS Press, 2, 1521-1528.

Arh, T./Dimovski, V./Jerman-Blažič, B. (2011): ICT and web 2.0 technologies as a determinant of business performace, in: Al-Mutairi, M.S., Lawan, A.M. (eds.): Cases on ICT utilization, practice and solutions: tools for managing day-to-day issues, Hershey, New York: Information Science Reference, 59-77. 
Bergant, Ž. (1998): Sodobni pogledi na ugotavljanje uspešnosti družbe, in: Slovenska ekonomska revija, 1-2, 87-101.

Bollen, K.A. (1989): Structural equations with latent variables. New York: Wiley.

Bontis, H./Crossan, M./Hulland, J. (2002): Managing an organizational learning system by aligning stocks and flows. Journal of Management Studies, 39, 4, 437-469.

Cangelosi, V.E./Dill, W.R. (1965): Organizational learning: observations toward a theory, in: Administrative Science Quarterly, 10, 175-203.

Cohen, W.M./Levinthal, D.A. (1990): Absorptive capacity: A new perspective on learning and innovation, in: Administrative Science Quarterly, 35, 1, 128-152.

Cyert, R.M./March, J.G. (1963): Behavioural Theory of the Firm. Englewood Cliffs: Prentice Hall.

Darr, E.D./Argote, L./Epple, D. (1995): The acquisition, transfer, and depreciation of knowledge in service organizations: Productivity in franchises, in: Management Science, 41, 11, 1750-1762.

Diamantopoulos, A./Siguaw, J.A. (2000): Introducing LISREL. London: SAGE Publications.

DiBella, J.A./Nevis, E.C. (1998): How Organizations Learn - An Integrated Strategy for Building Learning Capability. San Francisco, CA: Jossey-Bass.

Dimovski, V. (1994): Organisational learning and competitive advantage. PhD, Cleveland State University.

Dimovski, V./Colnar, T. (1999): Organizacijsko učenje, in: Teorija in praksa, 5, 36, 701-722.

Dimovski, V./Škerlavaj, M. (2005): Performance effects of organizational learning in a transitional economy, in: Problems and Perspectives in Management, 3, 4, 56-67.

Dimovski, V./Škerlavaj, M./Kimman, M./Hernaus, T. (2007): Proces organizacijskega učenja v slovenskih, hrvaških in malezijskih podjetjih, in: Management, 1, 2, 101-113.

Easterby-Smith, M./Crossan, M./Nicolini, D. (2000): Organizational Learning: Debates Past, Present and Future, in: Journal of Management Studies, 37, 6, 783-796.

Figueiredo, P.N. (2003): Learning processes features: How do they influence inter-firm differences in technological capability - Accumulation paths and operational performance improvement?, in: International Journal of Technology Management, 26, 7, 655-689.

Freeman, E.R. (1984): Strategic Management - A Stakeholder Approach, London: Pitman.

Freeman, E.R. (1994): Politics of Stakeholder Theory: Some Future Directions, Business, in: Ethics Quarterly, 4, 409-422.

Gerbing, D.W./Anderson, J.C. (1988): An updated paradigm for scale development incorporating unidimensionality and measurement error, in: Journal of Marketing Research, 25, 5, 186-192.

Goh, S./Richards, G. (1997): Benchmarking the learning capability of organizations, in: European Management Journal, 15, 5, 575-583.

Gold, A.H./Malhotra, A./Segars, A.H. (2001): Knowledge management: An organizational capabilities perspective, in: Journal of Management Information Systems, 18, 1, 185 214. 
Grant, R.M. (1996): Prospering in dynamically-competitive environments: organizational capability as knowledge integration, in: Organization Science, 7, 4, 375-387.

Huber, G.P. (1991): Organizational Learning: The Contributing Processes and the Literatures, in: Organization Science, 2, 1, 88-115.

Jimenez-Jimenez, D./Cegarra-Navarro, J.G. (2006): The Performance Effects of Organizational Learning and Market Orientation. Industrial Marketing Management.

Jones, G.R. (2000): Organizational Theory ( $3^{\text {rd }}$ ed.). New York: Prentice Hall.

Jöreskog, K.G./Sörbrom, D. (1993): LISREL 8: Structural Equation Modelling with the SIMPLIS Command Language, London: Lawrence Erlbaum Associates Publishers.

Kaplan, R.S./Norton, D.P. (1992): Balanced Scorecard - Measures That Drive Performance, in: Harvard Business Review, 1-2, 71-79.

King, D.W. (1980): Key papers in the economics of information, New Plains, New York: Knowledge Industry Publications.

Kovač, J./Jesenko, M. (2010): The connection between trust and leadership styles in Slovene organizations, in: Journal for East European Management Studies, 15, 1, 9-33.

Lei, D./Hitt, M.A./Bettis, R. (1996): Dynamic core competencies through meta-learning and strategic context, in: Journal of Management, 22, 4, 549-569.

Lei, D./Slocum, J.W./Pitts, R.A. (1999): Designing organizations for competitive advantage: The power of unlearning and learning, in: Organizational Dynamics, 27, 3, 24-38.

Leonard-Barton, D. (1992): The factory as a learning laboratory, in: Sloan Management Review, 34, 1, 23-38.

Levitt, B./March, J.G. (1998): Organizational learning, in: Annual Review of Sociology, 14, 319-340.

MacManus, R./Porter, J. (2005): Web 2.0 for design: bootstrapping the social web. Digital Web Magazine, 4.

Mintzberg, H. (1990): Strategy formation: Schools of thought, in: Frederickson, J.W. (ed.): Perspectives of strategic management, New York: Harper Business, 105-235.

Mueller, R.O. (1996): Basic Principles of Structural Equation Modeling: An Introduction to Lisrel and EQS. New York: Springer.

Nelson, R.R./Winter, S.G. (1982): An evolutionary theory of economic change. Cambridge: Belknap Press.

Nonaka, I./Takeuchi, H. (1996): A Theory of Organizational Knowledge Creation, in: International Journal of Technology Management, 11, 7/8, 833-846.

O'Reilly, T. (2005): What Is Web 2.0. Design Patterns and Business Models for the Next Generation of Software. Accessible at: http://oreilly.com/web2/archive/what-is-web20.html.

Pawlowsky, P./Forslin, J./Reinhardt, R. (2001): Practices and tools of organizational learning, in: Dierkes, M./Berthoin, A./Child, J./Nonaka,I. (eds.): Handbook of organizational learning and knowledge, New York' Oxford University Press Inc,775-793. 
Péréz-López, S./Montes-Peón, J.M./Vázquez-Ordás, C. (2004): Managing knowledge: The link between culture and organizational learning, in: Journal of Knowledge Management, 8, 6, 93-104.

Pisano, G.M./Bohmer, R.M.J./Edmondson, A.C. (2001): Organizational differences in rates of learning: Evidence from the adoption of minimally invasive cardiac surgery, in: Management Science, 47, 6, 752-768.

Real, J.C./Leal, A./Rolda, J.L. (2006): Information technology as a determinant of organizational learning and technological distinctive competencies, in: Industrial Marketing Management, 35, 505- 521.

Senge, P.M. (1990): The fifth discipline: art and practice of the learning organization. New York: Doubleday.

Shrivastava, P.A. (1983): Typology of Organizational Learning Systems, in: Journal of Management Studies, 20, 1-28.

Škerlavaj, M./Dimovski, V. (2004): Study of the mutual connections among informationcommunication technologies, organisational learning and business performance. Journal of East European Management Studies, 11, 1, 9-29.

Škerlavaj, M./Dimovski, V. (2006): Social network approach to organizational learning. The Journal of Applied Business Research, 22(2), 89-98.

Škerlavaj, M./Indihar Štemberger, M./Škrinjar, R./Dimovski, V. (2007): Organizational learning culture - the missing link between business process change and organizational performance. International Journal of Production Economics, 106, 2, 346-367.

Slater, S.F./Narver, J.C. (1995). Market orientation and the learning organization, in: Journal of Marketing, 59, 3, 63-74.

Sloan, T.R./Hyland, P.W.B./Beckett, R.C. (2002): Learning as a competitive advantage: Innovative training in the Australian aerospace industry, in: International Journal of Technology Management, 23, 4, 341-52.

Ulrich, D./Jick, T./Von Glinow, M.A. (1993): High-impact learning: Building and diffusing learning capability, in: Organizational Dynamics, 22, 2, 52-66.

Wall, B. (1998): Measuring the Right Stuff: Identifying and Applying the Right Knowledge, in: Knowledge Management Review, 1, 4, 20-24.

Zhang, D./Nunamaker, J.F. (2003). Powering e-learning in the new millennium: an overview of e-learning and enabling technology, in: Information Systems Frontiers, 5, 2, 207218. 